\title{
A NEW OCCURRENCE OF SAMUELSONITE IN THE BURANGA PEGMATITE, RWANDA
}

\author{
ANDRÉ-MATHIEU FRANSOLET, OLEG VON KNORRING and FRANÇOIS FONTAN
}

\begin{abstract}
FRANSOLET, ANDRÉ-MATHIEU, VON KNORRING, OLEG \& FONTAN, FRANCYIS, 1992. A new occurrence of samuelsonite in the Buranga pegmatite, Rwanda. Bull. Geol. Soc. Finland 64, Part 1, 13-21.

A new occurrence of the rare mineral species, samuelsonite, is reported from the Buranga pegmatite, Rwanda, in close association with gatumbaite and burangaite, as aggregates of bladed crystals imbedded in trolleite and in bertossaite.

Its crystallographic properties, determined both by the rotation and Weissenberg techniques and by the powder method, are: $a=18.621(3), b=6.842(1), c=$ $14.066(2) \AA, \beta=112^{\circ} 30^{\prime}\left(1^{\prime}\right), C 2 / m, Z=2 . G_{\text {meas. }}=3.24(5)$ and $G_{\text {calc. }}=3.22$. A wet chemical analysis gives: $43.79 \mathrm{P}_{2} \mathrm{O}_{5}, 6.18 \mathrm{Al}_{2} \mathrm{O}_{3}, 0.07 \mathrm{Fe}_{2} \mathrm{O}_{3}, 7.92 \mathrm{FeO}, 8.91 \mathrm{MnO}$, $0.07 \mathrm{MgO}, 28.41 \mathrm{CaO}, 2.31 \mathrm{BaO}, 0.43 \mathrm{Li}_{2} \mathrm{O}, 0.35 \mathrm{Na}_{2} \mathrm{O}, 1.85 \mathrm{H}_{2} \mathrm{O}^{+}$, total $100,29 \%$. Because of some structural similarities with the apatite structure, a few assigments of the infrared absorption bands are tentatively proposed.

A discussion on the crystal chemistry shows that Li resides in the octahedral $\mathrm{M}$ sites, whereas $\mathrm{Na}$ is sequestred with the excess of $\mathrm{Mn}$ and $\mathrm{Ca}$ in the $\mathrm{X}$ sites of the structure.
\end{abstract}

Key words: minerals, phosphates, samuelsonite, chemical composition, infrared spectra, crystal structure, pegmatite, Buranga, Rwanda.

André-Mathieu Fransolet, Institut de Minéralogie, Bât. B18, Université de Liège, Sart-Tilman, B - 4000 Liège, Belgium

Oleg von Knorring, Department of Earth Sciences, The University, Leeds LS2 9JT, England

François Fontan, Laboratoire de Minéralogie - U.R.A.67 Université Paul-Sabatier Allées Jules-Guesde, 39 F- 31400 Toulouse, France

\section{Introduction}

A re-examination of the phosphate minerals from the Buranga pegmatite, Rwanda (von Knorring 1972) showed that one of the major constituents of the Al-rich phosphate masses is trolleite, the common associated minerals being montebrasite, scorzalite, bertossaite, brazilianite, and apatite $s . l$. In that paper, von Knorring also recorded a new barium mineral, which has been identified as bjarebyite (von Knorring and Fransolet 1975), and gave the $d$-spacings for two undetermined fibrous phosphates. One of them, occurring as white rosettes, has been described as gatumbaite (von Knorring and Fransolet 1977). The purpose of the present paper is to discuss the results of the mineralogical investigation of the second one, tentatively thought to be another $\mathrm{Ba}$ bearing greenish phosphate (von Knorring and Fransolet 1977) and finally identified as samuelsonite.

\section{Physical and optical properties}

In the trolleite masses from Buranga, samuelsonite occurs as fan-like aggregates of bladed crystals. They have irregular contours and can 
Table 1: Optical properties.

\begin{tabular}{lcc}
\hline & Buranga & $\begin{array}{c}\text { Palermo No. 1 } \\
\text { (Moore et al. 1975) }\end{array}$ \\
\hline Sign & + & + \\
$\alpha \dagger$ & $1.648(2)$ & $1.645(2)$ \\
$\beta$ & $1.655(2)$ & $1.650(2)$ \\
$\gamma$ & $1.667(2)$ & $1.655(2)$ \\
$2 \mathrm{~V}_{\text {obs. }}$ & $80-85^{\circ}$ & large $\left(70-80^{\circ}\right)$ \\
$2 \mathrm{~V}_{\text {calc. }}$ & $75^{\circ}$ & - \\
$\mathrm{X} \Lambda$ trace & $31(2)^{\circ}$ & - \\
of $\{001\}$ & - & $22^{\circ}$ \\
Extinction & & \\
\hline
\end{tabular}

$\dagger$ The indices were measured for $\lambda_{\mathrm{Na}}=589 \mathrm{~nm}$.

reach up to $2 \mathrm{~cm}$, particularly in the specimen R.G.M. 9979 provided by the Musée royal de l'Afrique centrale in Tervuren, Belgium. Although the aggregates appear yellow green to pale green in colour, fragments of the pure mineral are colourless and transparent. Some altered grains are partly turbid. It must be noted that the greenish colour is caused by a very thin coating of undetermined olive green impurities in the cleavages and fractures of the mineral. The luster is vitreous on the perfect $\{001\}$ cleavage, and vitreous to resinous on the irregular fractures. The specific gravity $=3.24(5)$ was obtained on six selected grains using a Berman balance.

Isolated crystals are tabular on $\{001\}$ and elongated along [010]. As initially observed on the type mineral from the Palermo No. 1 pegmatite (Moore et al. 1975), all the crystals are finely striated parallel to $b$ on $\{001\}$. No forms were observed, and no twinning was found.

The optical properties, determined both on isolated grains and in thin sections, are compared in Table 1 with the data of Moore et al. (1975). The value for $2 \mathrm{~V}=(+) 80-85^{\circ}$ has been estimated on the frequent sections perpendicular to the optical axis, as previously noted by Moore et al. (1975). In thin section, laths with the trace of the $\{001\}$ cleavage show a negative elongation and, in the optic axial plane, the angle between $\mathrm{X}$ and the $\{001\}$ cleavage is $31\left(2^{\circ}\right)$. The dispersion $r<v$, is weak but distinct. The optical orientation is: $Y / / b$ and O.A.P. //(010).

\section{Description of the association}

Under the polarizing microscope, the material availabe for this study shows samuelsonite occurring as bundles of bladed crystals, colourless in thin section. Samuelsonite clearly corrodes trolleite, bertossaite, and scorzalite. It is accompanied by late apatite with an interstitial texture. Rosettes of gatumbaite, sometimes intimately intergrown with thin laths, or even with small sheafs, of burangaite intensely pleochroic in blue hues (von Knorring et al. 1977) appear at the contact of samuelsonite with trolleite. As gatumbaite also occurs within the aggregates of samuelsonite, cross-cutting its bladed crystals it seems justified to propose the following transformation, samuelsonite - apatite $\rightarrow$ gatumbaite - burangaite, as a step of the late evolution stage observed so far for the Al-rich phosphate associations in the Buranga mine. No bjarebyite has been recognized in this material.

\section{Crystallographic properties}

The X-ray diffractometer data obtained on the amount of handpicked samuelsonite selected for the wet chemical analysis are listed in Table 2 . Although they are similar to those given by Moore et al. (1975), our data, however, show $d$ values which are systematically a little larger. Moreover, a few $d$-values recorded by these authors are missing in our data, while we measured some additional $d$-spacings, for instance, $8.59 \AA$ (200) and $3.419 \AA$ (020). These differences do not seem to be attributable to the diffractometer technique used, which certainly gave reliable resolution of the $d$-values between 3.100 and $3.030 \AA$.

The cell parameters preliminarily measured on single crystal patterns using the rotation and 
Table 2: X-ray powder data of samuelsonite from Buranga.

\begin{tabular}{|c|c|c|c|c|c|c|c|}
\hline I/Io & $d_{\text {obs. }}(\AA)$ & $h k l$ & $d_{\text {calc }}(\AA)$ & I/Io & $d_{\text {obs. }}(\AA)$ & $h k l$ & $d_{\text {calc. }(\AA)}$ \\
\hline 10 & 13.01 & 001 & 12.995 & 5 & 2.507 & 421 & 2.507 \\
\hline 30 & 8.59 & 200 & 8.602 & 5 & 2.439 & $\overline{5} 15$ & 2.438 \\
\hline 10 & 6.172 & 201 & 6.168 & & & $\overline{7} 13$ & 2.437 \\
\hline 5 & 6.059 & $\overline{1} 11$ & 6.059 & $40 \mathrm{~b}$ & 2.316 & 602 & 2.316 \\
\hline 15 & 4.648 & $\overline{4} 01$ & 4.648 & & & $\overline{7} 14$ & 2.320 \\
\hline 15 & 4.455 & $\overline{4} 02$ & 4.456 & & & 710 & 2.313 \\
\hline 20 & 4.396 & 310 & 4.395 & 5 & 2.217 & 404 & 2.216 \\
\hline 10 & 4.299 & 400 & 4.301 & & & $\overline{3} 16$ & 2.218 \\
\hline 5 & 3.882 & $\overline{4} 03$ & 3.884 & $10 \mathrm{~b}$ & 2.141 & $\overline{3} 31$ & 2.140 \\
\hline \multirow[t]{2}{*}{10} & 3.840 & 311 & 3.836 & 5 & 2.105 & $\overline{3} 32$ & 2.104 \\
\hline & & $\overline{1} 13$ & 3.841 & 10 & 2.070 & 025 & 2.069 \\
\hline 10 & 3.685 & 401 & 3.684 & & & 621 & 2.069 \\
\hline 55 & 3.419 & 020 & 3.421 & $10 \mathrm{~b}$ & 2.001 & 801 & 2.002 \\
\hline 25 & 3.382 & 203 & 3.384 & 15 & 1.991 & & \\
\hline 15 & 3.306 & 021 & 3.308 & 10 & 1.977 & & \\
\hline 35 & 3.259 & $\overline{4} 04$ & 3.261 & 10 & 1.937 & & \\
\hline 20 & 3.176 & $\overline{2} 20$ & 3.179 & 10 & 1.921 & & \\
\hline 40 & 3.100 & $\overline{6} 02$ & 3.097 & 10 & 1.902 & & \\
\hline 100 & 3.078 & $\overline{3} 14$ & 3.080 & 10 & 1.895 & & \\
\hline 40 & 3.053 & $\overline{6} 01$ & 3.057 & 10 & 1.886 & & \\
\hline 20 & 3.030 & $\overline{2} 22$ & 3.029 & 10 & 1.854 & & \\
\hline 5 & 2.971 & $\overline{6} 03$ & 2.971 & 10 & 1.842 & & \\
\hline 20 & 2.870 & $\overline{6} 00$ & 2.867 & 15 & 1.820 & & \\
\hline 50 & 2.803 & $\overline{2} 05$ & 2.802 & 20 & 1.711 & & \\
\hline \multirow[t]{2}{*}{40} & 2.754 & $\overline{4} 21$ & 2.755 & & & & \\
\hline & & $\overline{2} 23$ & 2.755 & & & & \\
\hline 40 & 2.709 & 222 & 2.708 & & & & \\
\hline 65 & 2.677 & 420 & 2.677 & & & & \\
\hline \multirow[t]{2}{*}{50} & 2.595 & 403 & 2.596 & & & & \\
\hline & & $\overline{3} 15$ & 2.595 & & & & \\
\hline 5 & 2.568 & $\overline{4} 23$ & 2.567 & & & & \\
\hline
\end{tabular}

b: broad. Diffractometer; monochromatized Fe radiation; $d$ values corrected with an internal standard $\mathrm{Pb}\left(\mathrm{NO}_{3}\right)_{2}(a=$ $7.8568 \AA$ ).

Table 3. Unit-cell data.

\begin{tabular}{lll}
\hline & \multicolumn{1}{c}{ Buranga } & \multicolumn{1}{c}{$\begin{array}{c}\text { Palermo No. 1 } \\
\text { (Moore and Araki, 1977) }\end{array}$} \\
\hline$a(\AA)$ & $18.621(3)$ & $18.495(10)$ \\
$b(\AA)$ & $6.842(1)$ & $6.805(4)$ \\
$c(\AA)$ & $14.066(2)$ & $14.000(8)$ \\
$\beta$ & $112^{\circ} 30^{\prime}\left(1^{\prime}\right)$ & $112.75(6)^{\circ}$ \\
$V\left(\AA^{3}\right)$ & $1655.6(3)$ & 1624.9 \\
$a: b: c^{(1)}$ & $2.722: 1: 2.056$ & $2.718: 1: 2.057$ \\
Space group & $C 2 / m$ & $C 2 / m$ \\
$Z$ & 2 & 2 \\
$\mathrm{D}_{\text {meas. }}$ & $3.24(5)$ & 3.353 \\
$\mathrm{D}_{\text {calc. }}$ & 3.22 & 3.355 \\
\hline
\end{tabular}

(1) calculated from the unit-cell parameters.
Weissenberg methods were refined from the powder data. These calculated cell dimensions, compared with the data of Moore and Araki (1977) in Table 3, show that the unit-cell of the Buranga samuelsonite is decidedly larger than that of the type samuelsonite from the Palermo No. 1 pegmatite. The interpretation of the Weissenberg patterns results in the determination of the space group $C 2 / m, C 2$ or $C m$ and we adopt $C 2 / m$ in Table 3, in accordance with Moore and Araki (1977) who solved the crystal structure. 

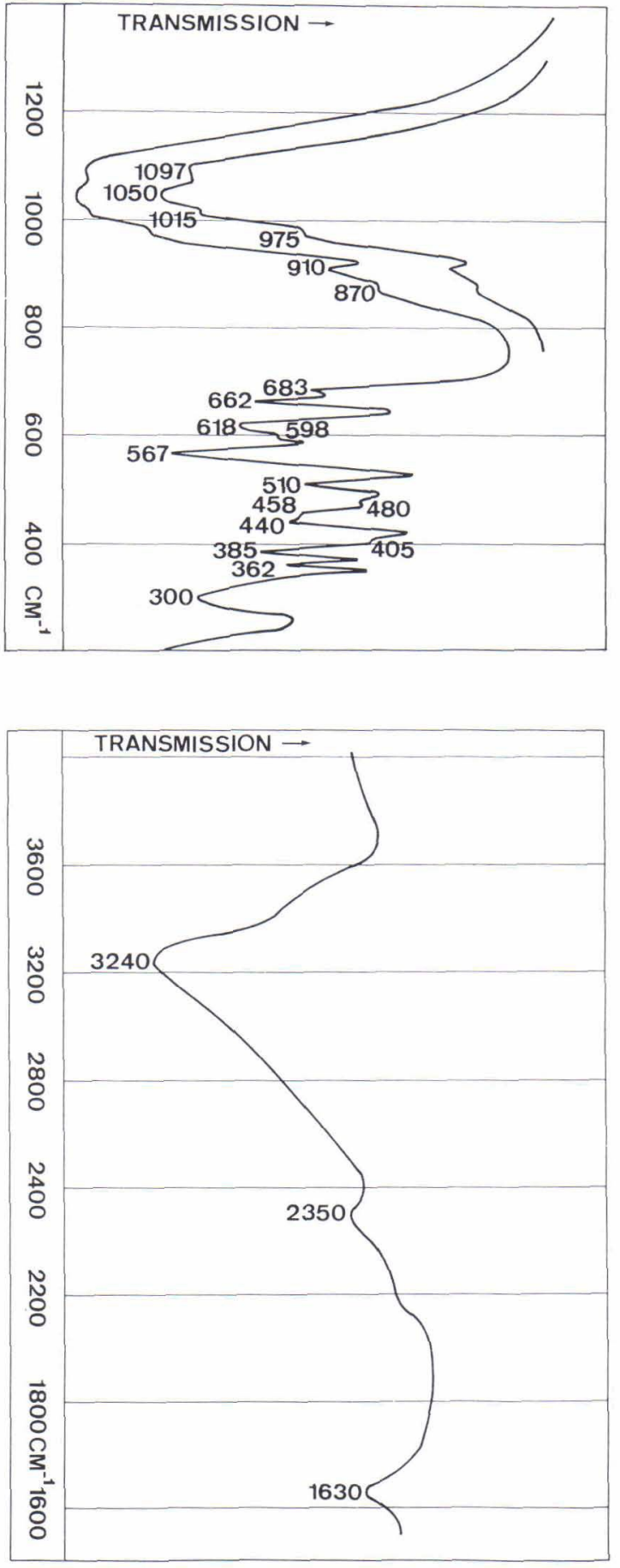

Fig. 1. Infrared spectra of the Buranga samuelsonite.

1a) $200-1300 \mathrm{~cm}^{-1}$ domain $(2.5 \mathrm{mg}$ of material diluted in $0.6 \mathrm{gr} \mathrm{KBr})$.

1b) $1500-4000 \mathrm{~cm}^{-1}$ domain (6 mg diluted in $0.6 \mathrm{gr} \mathrm{KBr}$ ).

\section{Infrared absorption spectrum}

An infrared spectrum has been recorded between $200 \mathrm{~cm}^{-1}$ and $4000 \mathrm{~cm}^{-1}$ with a Beckman IR 4250 spectrophotometer following the conventional pressed-pellet technique. A $2.5 \mathrm{mg}$ sample of samuelsonite was carefully ground and mixed with $0.6 \mathrm{~g} \mathrm{KBr}$, and the mixture pressed as to give a disc of $20 \mathrm{~mm}$ diameter for the domain between $200 \mathrm{~cm}^{-1}$ and $1400 \mathrm{~cm}^{-1}$ (Fig. 1a). For the range $1500-4000 \mathrm{~cm}^{-1}, 6 \mathrm{mg}$ were mixed with the same amount of $\mathrm{KBr}$ (Fig. 1b). The observed absorption band frequencies are directly indicated on the spectra.

In the complex part of the spectrum shown in Figure 1a, there is little doubt about the assignment of the strong absorption bands between 950 $\mathrm{cm}^{-1}$ and $1100 \mathrm{~cm}^{-1}$ to the antisymmetric vibrations of the $\mathrm{PO}_{4}$ anion. It seems also reasonable to attribute the band at $975 \mathrm{~cm}^{-1}$ to the $v_{1}$ vibration, and those at $1015 \mathrm{~cm}^{-1}, 1050 \mathrm{~cm}^{-1}$ and 1097 $\mathrm{cm}^{-1}$ to the $U_{3}$ vibrations of $\mathrm{PO}_{4}$, respectively. The shape of these bands in a relatively narrow domain suggests that the $\mathrm{PO}_{4}$ tetrahedra are moderately distorted, what is in agreement with the P-O distances measured by Moore and Araki (1977). Additionally, if we take the similarities between particular sections of the samuelsonite atomic arrangement and the apatite structure into account, as reported by these authors, it appears that the four frequencies measured on the samuelsonite spectrum are very close to the ones already known for the $v_{1}-v_{3}$ vibrations of the $\mathrm{PO}_{4}$ anion in the minerals with an apatite structure (Table 17 in Ross, 1974). By extending further our comparison, we are inclined to consider the strong absorption bands occurring at 567 $\mathrm{cm}^{-1}, 598 \mathrm{~cm}^{-1}$ and $618 \mathrm{~cm}^{-1}$ as the $\mathrm{v}_{2} \mathrm{PO}_{4}$ bending, again with both their frequencies and relative intensities quite similar to that of apatite. Although both the $\mathrm{PO}_{4}$ bending and $\mathrm{AlO}_{6}$ stretching vibrations contribute to the absorption in this $650-500 \mathrm{~cm}^{-1}$ region (Povarennykh, 1978), we speculate that the doublet at $662-683 \mathrm{~cm}^{-1}$ 
could be due to the stretching vibrations of the octahedral Al.

From the $1500-4000 \mathrm{~cm}^{-1}$ region (Fig. 2b), it is virtually impossible to identify of $\mathrm{O}-\mathrm{H}$ stretching vibration of the hydroxyl groups because they are certainly screened by the stretching vibrations of $\mathrm{H}_{2} \mathrm{O}$. This strong and large absorption band seems to indicate by its frequency at $3240 \mathrm{~cm}^{-1}$, that $\mathrm{H}_{2} \mathrm{O}$ is rather strongly bonded in the struc- ture. However, the weak shoulder observed towards the higher frequencies, around $3400 \mathrm{~cm}^{-1}$, is probably caused by a second type of $\mathrm{H}_{2} \mathrm{O}$, less strongly bonded. The two other bands at $1630 \mathrm{~cm}^{-1}$ and $2350 \mathrm{~cm}^{-1}$ can be attributed to the bending vibration of the water molecules, and to an harmonic or a combination vibration, respectively.

Table 4: Chemical analyses of samuelsonite

1. Wet-chemical analysis performed by O.v.K.; $\left({ }^{*}\right)$ the sum includes 0.28 wt. $\%$ insoluble.

2. Wet-chemical analysis performed by J.-M. Speetjens.

3. „Find 1»: electron microprobe analysis by A.J. Irving (Moore et al. 1975).

4. »Find 2»; wet chemical analysis by J. Ito (Moore et al. 1975).

5. Theoretical composition for the charge balanced formula $\left(\mathrm{Ba}_{0.5} \square_{0.5}\right)\left(\mathrm{Ca}_{0.5} \square_{0.5}\right)_{2}\left(\mathrm{Mn}_{0.45} \mathrm{Fe}_{0.30} \mathrm{Na}_{0.25}\right)_{4} \mathrm{Ca}_{8} \mathrm{Al}_{2}\left(\mathrm{PO}_{4}\right)_{10}\left(\mathrm{OH}_{2}\right.$ (Moore and Araki, 1977).

tr. :traces; n.d.: not determined.

$\mathrm{R}=\mathrm{Mn} /\left(\mathrm{Mn}+\mathrm{Fe}^{2+}\right)$.

\begin{tabular}{|c|c|c|c|c|c|}
\hline & \multicolumn{2}{|c|}{ Buranga } & \multicolumn{3}{|c|}{ Palermo No. 1} \\
\hline & 1 & 2 & 3 & 4 & 5 \\
\hline $\mathrm{P}_{2} \mathrm{O}_{5}$ & 42.76 & 43.79 & 44.0 & 43.10 & 42.86 \\
\hline $\mathrm{Al}_{2} \mathrm{O}_{3}$ & 6.37 & 6.18 & 6.2 & 4.80 & 6.16 \\
\hline $\mathrm{Fe}_{2} \mathrm{O}_{3}$ & 1.48 & 0.07 & - & nil & - \\
\hline $\mathrm{FeO}$ & 7.26 & 7.92 & 6.5 & 11.30 & 5.21 \\
\hline $\mathrm{MnO}$ & 8.81 & 8.91 & 7.9 & 7.20 & 7.71 \\
\hline $\mathrm{MgO}$ & - & 0.07 & - & 0.12 & - \\
\hline $\mathrm{CaO}$ & 26.96 & 28.41 & 29.6 & 28.30 & 30.48 \\
\hline $\mathrm{SrO}$ & - & - & 0.3 & 0.44 & - \\
\hline $\mathrm{BaO}$ & 2.65 & 2.31 & 4.8 & 2.04 & 4.63 \\
\hline $\mathrm{Li}_{2} \mathrm{O}$ & 0.42 & 0.43 & - & - & - \\
\hline $\mathrm{Na}_{2} \mathrm{O}$ & 0.44 & 0.35 & 1.4 & 0.21 & 1.87 \\
\hline $\mathrm{K}_{2} \mathrm{O}$ & 0.07 & $\operatorname{tr}$ & - & 0.02 & - \\
\hline $\mathrm{H}_{2}^{-\mathrm{O}^{+}}$ & 1.88 & 1.85 & n.d. & 3.00 & 1.09 \\
\hline $\mathrm{H}_{2} \mathrm{O}$ & 0.03 & - & - & - & - \\
\hline Total & $99.41^{*}$ & 100.29 & 100.7 & 100.53 & 100.01 \\
\hline \multicolumn{6}{|c|}{ Cation numbers calculated on the basis of $20.00 \mathrm{PO}_{4}$ per unit cell. } \\
\hline $\mathrm{A} 1^{3+}$ & 4.15 & 3.93 & 3.92 & 3.10 & 4.00 \\
\hline $\mathrm{Fe}^{3+}$ & 0.62 & 0.03 & - & - & - \\
\hline $\mathrm{Fe}^{2+}$ & 3.35 & 3.57 & 2.92 & 5.18 & 2.40 \\
\hline $\mathrm{Mn}^{2+}$ & 4.12 & 4.07 & 3.59 & 3.34 & 3.60 \\
\hline $\mathrm{Mg}^{2+}$ & - & 0.06 & - & 0.10 & - \\
\hline $\mathrm{Ca}^{2+}$ & 15.96 & 16.42 & 17.03 & 16.62 & 18.00 \\
\hline $\mathrm{Sr}^{2+}$ & - & - & 0.09 & 0.14 & - \\
\hline $\mathrm{Ba}^{2+}$ & 0.57 & 0.49 & 1.01 & 0.44 & 1.00 \\
\hline $\mathrm{Li}^{+}$ & 0.93 & 0.93 & - & - & - \\
\hline $\mathrm{Na}^{+}$ & 0.47 & 0.36 & 1.46 & 0.22 & 2.00 \\
\hline $\mathrm{K}^{+}$ & 0.05 & - & - & 0.01 & - \\
\hline $\mathrm{H}^{+}$ & 6.93 & 6.66 & $?$ & 10.97 & 4.00 \\
\hline $\mathrm{R}$ & 0.55 & 0.53 & 0.55 & 0.39 & 0.60 \\
\hline
\end{tabular}




\section{Chemical composition}

In 1973 one of us (O.v.K.) performed a wet chemical analysis on this yellow green mineral but the results were never published. They are shown in Table 4, column 1.

Although the physical and optical features, as well as the crystallographic properties of the mineral described in this paper (Tables 1,2 and $3)$, corroborate the identification of samuelsonite, some discrepancies arise between the chemical results of O.v.K. and those given by Moore et al. (1975), i.e. the electron microprobe data, and a wet chemical analysis of Jun Ito (see Table 4). On the contrary of the samuelsonite from the Palermo pegmatite, the mineral from Buranga seems to contain significant amounts of $\mathrm{Fe}_{2} \mathrm{O}_{3}$, and of $\mathrm{Li}_{2} \mathrm{O}$; its $\mathrm{H}_{2} \mathrm{O}$ content in wt $\%$ is also different from the result obtained by $\mathrm{J}$. Ito.

As the material available at the outset of our reinvestigation only displayed small amounts of samuelsonite dispersed within trolleite, and intimately associated with scorzalite, and burangaite, a purification of the mineral of handpicking was unsuccessful. Moreover, as ferric iron and lithium could not be checked with the electron microprobe, a wet-chemical analysis still appears as the best way to solve the problem.

In the meantime, specimens from the mineral collection of the Museum at Tervuren provided us with new fresh material. A qualitative spectrographical analysis confirm $\mathrm{P}, \mathrm{Ca}, \mathrm{Al}, \mathrm{Fe}$, and $\mathrm{Mn}$ as major elements, $\mathrm{Ba}, \mathrm{Li}, \mathrm{Na}$ and $\mathrm{Mg}$ as minor elements, $\mathrm{Pb}, \mathrm{Ga}, \mathrm{Ti}, \mathrm{Cu}$ and $\mathrm{Ag}$ as trace elements. A wet-chemical analysis was performed on $25 \mathrm{mg}$ of selected transparent grains, and the Fe content was determined on another separated amount of $25 \mathrm{mg}$ following the method by Wilson (1960). The Penfield method served to determine the water content on $50 \mathrm{mg}$.

The new results are also given in Table 4 , column 2 and are very similar to those obtained some years before. Both the $\mathrm{Li}_{2} \mathrm{O}$ and $\mathrm{H}_{2} \mathrm{O}$ contents are virtually identical in the two analyses. The new data also show $\mathrm{Fe}_{2} \mathrm{O}_{3}$ is not constant; the $\mathrm{Fe}_{2} \mathrm{O}_{3}$ content obtained by O.v.K. was likely caused by undetermined impurities or alteration products coating the cleavages and fractures of the mineral (see before).

Nevertheless, in order to compare our data with those of Moore et al. (1975), a small transparent fragment of the fresh material was polished for electron microprobe analyses, using the full automated equipment Camebax SX50 (operating conditions: accelerating voltage $15 \mathrm{kV}$, sample current $20 \mathrm{nA}$ ). The following standards were used: graftonite from Kabira for $\mathrm{P}, \mathrm{Fe}, \mathrm{Mn}$ and $\mathrm{Ca}$; albite for $\mathrm{Al}$, and $\mathrm{Na}$; barite for $\mathrm{Ba}$. The results of these partial analyses are given in Table 5 .

Table 5: Electron microprobe analyses of the Buranga samuelsonite.

1 to 5: The five point-analysis on one crystal performed by F. Autefage with the Camebax SX50.

6: $\quad$ Mean values, $\bar{x}$ in $w t \%$, and the standard deviation of $\bar{x}$, s, given in parentheses.

7: $\quad$ Relative standard derivation of $\bar{x}, s / \bar{x}$, multiplied by 100 .

\begin{tabular}{lrrrrrrr}
\hline & \multicolumn{1}{c}{1} & \multicolumn{1}{c}{2} & \multicolumn{1}{c}{3} & \multicolumn{1}{c}{5} & 5 & 6 \\
\hline $\mathrm{P}_{2} \mathrm{O}_{5}$ & 42.19 & 41.86 & 40.87 & 40.87 & 41.12 & $41.38(0.61)$ & 1.47 \\
$\mathrm{Al}_{2} \mathrm{O}_{3}$ & 5.97 & 6.02 & 5.93 & 5.93 & 5.81 & $5.93(0.08)$ & 1.35 \\
$\mathrm{FeO}$ & 7.57 & 7.36 & 7.63 & 7.84 & 7.79 & $7.64(0.19)$ & 2.49 \\
$\mathrm{MnO}$ & 8.75 & 8.72 & 8.82 & 8.19 & 7.59 & $8.41(0.52)$ & 6.18 \\
$\mathrm{CaO}$ & 25.67 & 25.60 & 24.98 & 25.09 & 24.72 & $25.21(0.41)$ & 1.62 \\
$\mathrm{BaO}$ & 0.89 & 1.16 & 2.03 & 3.75 & 4.85 & $2.54(1.71)$ & 67.32 \\
$\mathrm{Na}_{2} \mathrm{O}$ & 0.48 & 0.49 & 0.28 & 0.20 & 0.10 & $0.31(0.17)$ & 55.84 \\
\hline
\end{tabular}

Cation numbers on the basis of $20.00 \mathrm{PO}_{4}$ per unit cell (for column 6 ): $\mathrm{Al}=3.99 ; \mathrm{Fe}^{2+}=3.65 ; \mathrm{Mn}=4.07 ; \mathrm{Ca}=15.42$; $\mathrm{Ba}=0.57 ; \mathrm{Na}=0.34 ; \mathrm{Mn} /(\mathrm{Mn}+\mathrm{Fe})=0.53$. 


\section{Discussion of the results}

The new wet-chemical analysis (Table 4) allows to calculate the cation numbers on the basis of $20\left[\mathrm{PO}_{4}\right]^{3-}$ in the unit-cell, and the distribution of the cations, as proposed by Moore et al. (1975), results in the following structural formula for the mineral from Buranga:
While the $\mathrm{Mn} /(\mathrm{Mn}+\mathrm{Fe})$ ratio in the Buranga samuelsonite averages 0.53 , and is virtually identical to the ratio obtained for the mineral of the Palermo mine (»Find $1 »$ ), it becomes 0.39 for the mineral called $»$ Find $2 »$ in the same mine (Moore et al. 1975). Marked variations of this ratio are known to occur in other phosphate minerals occurring as late products in granitic pegmatites.

$\begin{array}{ll}\mathrm{PO}_{4} & : 20.00 \\ \mathrm{Ca} & : 16.00 \\ \mathrm{~A} 1 & : 3.93 \mathrm{~A} 1+0.03 \mathrm{Fe}^{3+} \sim 4.00 \\ \mathrm{M}(1)+\mathrm{M}(2) & : 3.57 \mathrm{Fe}^{2+}+0.93 \mathrm{Li}+0.06 \mathrm{Mg}+3.44 \mathrm{Mn}^{2+}=8.00 \\ \mathrm{X}(2) & : 0.63 \mathrm{Mn}^{2+}+0.42 \mathrm{Ca}+0.36 \mathrm{Na}+2.59 \square=4.00 \\ \mathrm{X}(1) & : 0.49 \mathrm{Ba}+1.51 \square=2.00 \\ \mathrm{OH} & : 2.30 \mathrm{OH}^{-}+1.70 \mathrm{H}_{2} \mathrm{O}=4.00 \\ +0,48 \mathrm{H}_{2} \mathrm{O} & \end{array}$

With $\mathrm{Z}=2$, this formula gives a calculated specific gravity of $3.26 \mathrm{~g} / \mathrm{cm}^{3}$ in good agreement with the measured specific gravity. By using the revised constant published by Mandarino (1981) for the Gladstone-Dale relationship, we calculated $n=1.635$ and a compatibility index $\left(1-K_{p} / K_{c}\right)=-0.034$, which ranges the category »excellent» (Mandarino, 1981).

The relevant fragments of the samuelsonite structure, as defined by Moore and Araki (1977), are: the double column $\left[\mathrm{Ca}_{4}\left(\mathrm{PO}_{4}\right)_{10}\right]$, which is the common element with the apatite structure permitting some reasonable assignments of the complex infrared spectrum, and the cluster $\left[\mathrm{Ca}_{4} \mathrm{Al}_{2}(\mathrm{OH})_{2}\right]$ constituted by $\mathrm{Ca}(1), \mathrm{Ca}(2)$, and the $\left[\mathrm{Al}(\mathrm{OH}) \mathrm{O}_{4}\right]$ octahedral chain. Consequently, the available amounts of $\mathrm{A} 1$ and $\mathrm{Ca}$ atoms on the basis of $20\left(\mathrm{PO}_{4}\right)$ in the cell must reach at least 4 and 16, respectively, to build up a valid formula. A comparison with the results obtained by Moore et al. (1975) effectively shows that the $\mathrm{A} 1, \mathrm{Ca}$ and $\mathrm{P}$ contents are varying in a short range only.

On the other hand, the cationic contents in the other sites of the structure display very distinct variations.
The variations of the $\mathrm{Li}, \mathrm{Ba}$ and $\mathrm{H}_{2} \mathrm{O}$ contents are more puzzling.

In the proposed formula for the Buranga mineral, the small amount of $\mathrm{Li}(0.93$ atom per cell) is reasonally located in the octahedral $M(1)+M(2)$ sites. Subsequently, the excess of $\mathrm{Mn}^{2+}$ and the amount of $\mathrm{Na}$ reside in the $\mathrm{X}(2)$ site, normally populated by Ca. Nevertheless, it can be seen that the large amount of vacant $\mathrm{X}(2)$ positions (2.59), as well as the 1.51 empty $\mathrm{X}(1)$ positions, are in agreement with the description of Moore and Araki (1977, who reported that $\mathrm{X}(1)$ and $\mathrm{X}(2)$ must be at most half-filled for steric grounds.

A tiny crystal of samuelsonite from Palermo mine (U.S.N.M. 128.071) and labelled »Find 1», being thus considered as type material by Moore et al. (1975), was sacrificed for a qualitative check of $\mathrm{Li}$ by atomic absorption spectroscopy. Although the rather small available amount of the mineral prevents from obtaining accurate results, the presence of Li was detected, and its content was roughly estimated to be around $0.5 \mathrm{wt} . \%$. This observation forces us to conclude that the presence of a significant content of $\mathrm{Li}$ was not previously reported for the type mineral from 
Palermo.

The $\mathrm{Ba}$ variations were already mentioned in the two occurrences in the Palermo pegmatite (Table 4). In the case of Buranga, marked variations in the $\mathrm{Ba}$ contents were also detected thanks to the electron microprobe analyses, however, no zoning was seen. Although the microprobe results were obtained from five point-analyses only (Table 5), the average contents of the analysed elements are in fair agreement with the wet-chemical data. However, the $\mathrm{CaO}$ contents are rather low and one of the $\mathrm{MnO}$ values appears to be an analytical error. If the relative standard deviation of $\bar{x}, s / \bar{x}$, is taken into account (Table 5), the values indicated for $\overline{\mathrm{x}}_{\mathrm{P}_{2} \mathrm{O}_{5}}, \overline{\mathrm{x}}_{\mathrm{Al}_{2} \mathrm{O}_{3}}, \overline{\mathrm{x}}_{\mathrm{FeO}}$, and even for $\overline{\mathrm{x}}_{\mathrm{CaO}}$, may be considered as the normal analytical uncertainties of these element determinations by electron microprobe. The values of $s / \bar{x}$ noticed for $\overline{\mathrm{x}}_{\mathrm{BaO}}$ and $\overline{\mathrm{x}}_{\mathrm{Na}_{2} \mathrm{O}}$, higher than the above analytical uncertainty (Table 5), reflect the nonuniform distribution of both these components within the analysed fragment of samuelsonite. As it can be seen from Table 5, the variations of the $\mathrm{Ba}$ contents are very sensitive. The range $0.89-$ 4.85 wt. $\% \mathrm{BaO}$ gives an upper value, corresponding to 1.09 atom $\mathrm{Ba}$ in the unit-cell, which is virtually identical to the theoretical value considered by Moore and Araki (1977) for the ideal formula (Table 4). Additionally, from the few chemical data obtained, the increase of $\mathrm{Ba}$ appears to be accompanied by a decrease of $\mathrm{Na}$ (Table 5).

Although our interpretation of the chemical results is constructed on cation numbers calculated on the basis of $20\left(\mathrm{PO}_{4}\right)$ per unit cell and that Moore et al. (1975) computed the cell contents based on 84 oxygen, we cannot agree with the limited and, however, plausible replacement of $\left[\mathrm{PO}_{4}\right]$ tetrahedra by $\left[\mathrm{H}_{4} \mathrm{O}_{4}\right]$ as suggested by these authors to explain a relatively high water content for samuelsonite »Find 2» in Palermo (Table IV). However Moore and Araki (1977) did not envisage the role of $\mathrm{H}_{2} \mathrm{O}$ molecules in the crystal structure determination. They only specify the position of the $\mathrm{OH}$ groups in the shared corners of the Al octahedra. In order to balance the charges in our chemical formula, we are forced to consider $1.70 \mathrm{H}_{2} \mathrm{O}$ occurring in the sites theoretically populated by the $4 \mathrm{OH}$, and acting thus far as ligands of the A1-centered octahedra. Nevertheless, an excess of about $0.5 \mathrm{H}_{2} \mathrm{O}$ per unit cell subsists. Although it could be reasonably suggested that these additional water molecules could stabilize the structure of samuelsonite, in which the large $\mathrm{X}(1)$ and $\mathrm{X}(2)$ sites are partly vacant, the infrared analysis, however, did not provide us with valid arguments to locate $\mathrm{H}_{2} \mathrm{O}-$ or $\mathrm{H}_{3} \mathrm{O}^{+}-$in these particular sites.

As a conclusion, the comparison of our data, with those given for the two occurrences of samuelsonite in the Palermo mine, does not provide us with anything relevant. The discrepancy between the physical properties, which clearly appears from the Tables 1 and 3, cannot be reasonably justified so far. The chemical composition of this mineral is complex, and very flexible, as we have reported it here.

According to our chemical data, it seems that the role of $\mathrm{Na}^{+}$in the octahedral sites has been over-estimated by Moore and Araki (1977). We are of the opinion that the too low electron density distribution for $\mathrm{M}(1)$ and $\mathrm{M}(2)$, observed by these authors, is caused by $\mathrm{Li}^{+}$. Consequently, $\mathrm{Na}^{+}$must reside in the $\mathrm{X}(2)$ site with $\mathrm{Ca}$. Moreover, the calculation of the site occupancy for the Buranga samuelsonite leads us to consider a small amount of $\mathrm{Mn}^{2+}$, which must also populate the $\mathrm{X}(2)$ sites. It must be pointed out that similarly an excess of $\mathrm{Mn}^{2+}$ is also known to coexist with $\mathrm{Na}^{+}$and a low amount of $\mathrm{Ca}^{2+}$ in the $\mathrm{X}(1)$ sites of the alluaudites occurring in the lithium-rich pegmatite of Buranga (Moore, 1971; Fransolet, 1975).

Acknowledgements. We are indebted to Dr. M. Deliens for providing several specimens of trolleite from Buranga, to Dr. P.J. Dunn, for sending a fragment of the type material, to Prof. P. Tarte, for recording of the infrared spectra, and to M. Ortelli, for the qualitative analyses. One of us (A.-M. Fransolet) is also grateful to the F.N.R.S., Belgium, for his former position as Research Associate, and for research grants (1.5.222.82F and 1.5.017.89F).

The critical comments by Dr. J. Mandarino have considerably improved the earlier manuscript version. 


\section{References}

Fransolet, A.-M. (1975). Etude minéralogique et pétrologique des phosphates de pegmatites granitiques. Unpublished Ph.D. thesis, Inst. Minéralogie, University of Liège Belgique.

Mandarino, J.A. (1981). The Gladstone-Dale relationship. Part IV: The compatibility concept and its application. Canadian Mineralogist 19, 441-450.

Moore, P.B. (1971). Crystal chemistry of the alluaudite structure type: Contribution to the paragenesis of pegmatite phosphate giant crystals. American Mineralogist 56, 1955-1975.

Moore, P.B., Irving, A.J. and Kampf, A.R. (1975). Foggite, $\mathrm{CaA} 1(\mathrm{OH})_{2}\left(\mathrm{H}_{2} \mathrm{O}\right)\left[\mathrm{PO}_{4}\right]$; goedkenite, $(\mathrm{Sr}, \mathrm{Ca})_{2} \mathrm{Al}(\mathrm{OH})$ $\left[\mathrm{PO}_{4}\right]^{-4}$; and samuelsonite, $(\mathrm{Ca}, \mathrm{Ba}) \mathrm{Fe}_{2}^{2+} \mathrm{Mn}_{2}^{2+} \mathrm{Ca}_{8} \mathrm{Al}_{2}$ $(\mathrm{OH})_{2}\left[\mathrm{PO}_{4}\right]_{2}$ : Three new species from the Palermo No. 1 pegmatite, North Groton, New Hampshire. American Minerologist 60, 957-964.

Moore, P.B. and Araki, T. (1977). Samuelsonite: its crystal structure and relation to apatite and octacalcium phosphate. American Mineralogist 62, 229-245.

Povarennykh, A.S. (1978). The use of infrared spectra for the determination of minerals. American Mineralogist 63, 956-959.

Ross, S.D. 1974). Phosphates and other oxy-anions of group V. In V.C. Farmer, Ed., Infrared Spectra of Minerals, 382-422. Miner. Soc., Monograph 4.

Von Knorring, O. (1972). Notes on phosphate minerals from Buranga pegmatite, Rwanda. 16th Ann. Rep. Research Inst. African Geol., Univ. Leeds, 56-57.

Von Knorring, O. and Fransolet, A.-M. (1975). An occurrence of bjarebyite in the Buranga pegmatite, Rwanda. Schweitz Mineral. Petr. Mitt. 55, 9-18.

Von Knorring, O. and Fransolet, A.-M. (1977). Gatumbaite, $\mathrm{CaAl}_{2}\left(\mathrm{PO}_{4}\right)_{2}(\mathrm{OH})_{2} \cdot \mathrm{H}_{2} \mathrm{O}$ : a new species from Buranga pegmatite, Rwanda. N. Jb. Mineral. Mh. 1977, 561-568.

Von Knorring, O., Lehtinen, M. and Sahama, Th.G. (1977). Burangaite, a new phosphate mineral from Rwanda. Bulletin of the Geological Society of Finland, 49, 33-36.

Wilson, A.D. (1960). The micro-determination of ferrous iron in silicate minerals by a volumetric and a colorimetric method. Analyst 85, n' $1016,823-827$.

Received October 10, 1991

Revision accepted November 2, 1991 